\title{
Significance of Dietary Antioxidants in Averting Cancer
}

\section{Subrahmanyam V ${ }^{1 *}$ and Radhika P Ramachandran ${ }^{2 *}$}

${ }^{1}$ Department of Biochemistry, School of Life sciences, University of Hyderabad, Hyderabad

${ }^{2}$ Department of Biotechnology, Faculty of Engineering and Technology, SRM University, Chennai

\begin{abstract}
Reactive oxygen species are constantly produced in our body due to various factors like environmental pollution, unhealthy diet habits, cellular metabolism etc. Epidemiological studies suggest that the intakes of antioxidants are inversely related to the cancer risk. While the cell culture studies confirm the effect of antioxidants against cancer, the clinical trials remains inconclusive. The human population is heterogeneous regarding Reactive oxygen species (ROS), so screening the human population for developing the risk of cancer will provide a scientific ground for the application of antioxidants. Research is increasingly showing that those who eat antioxidant-rich foods reap health benefits. Foods, rather than supplements, may boost antioxidant levels because foods contain an unmatchable array of antioxidant substances.
\end{abstract}

Keywords: Reactive oxygen species; Free radical; tumor; Dietary antioxidants

\section{Introduction}

An uncontrolled rapid cell growth/division or proliferation can be called as cancer. A cancerous cell to be called as malignant tumor where as normal cell called as benign tumor [1]. Although there are many kinds of cancer, they all start because abnormal cells grow out of control. Untreated cancers can cause serious illness and it also may leads to death. There are many kinds of cancer, but they all start because of out-of-control growth of abnormal cells. Different types of cancer can behave very differently. For example, lung cancer and breast cancer are very different diseases [2]. They grow at different rates and respond to different treatments. That is why people with cancer need treatment that is aimed at their particular kind of cancer [3]. Causes of cancer, including genetic factors; lifestyle factors such as tobacco use, diet, and physical activity; certain types of infections; and environmental exposures to different types of chemicals and radiation [4]

Dietary antioxidants are substance that protects cells, tissues and DNA against the oxidative damage by free radicals. Dietary antioxidants include the micronutrients like vitamin A, vitamin $\mathrm{C}$ (ascorbic acid), vitamin E, beta-carotene, bioflavonoid and polyphenols etc [5]. Dietary antioxidants will help to reduce the free radicals circulating inside the body. Various dietary antioxidants have shown considerable promise as effective agents for cancer prevention by reducing oxidative stress which has been implicated in the development of many diseases, including cancer. Therefore, for reducing the incidence of cancer, modifications in dietary habits, especially by increasing consumption of fruits and vegetables rich in antioxidants are increasingly advocated. Numerous epidemiological studies have conducted to test the role of dietary antioxidants on prevention of cancer and vitamin $\mathrm{C}$ is found to have most significant effect [6]. Reactive oxygen species are produced inside the body as a result of cellular metabolism or the effect of environmental factors such as pollution and certain dietary factors. Dietary antioxidants act as a biological defense against cancer prevention. Vitamin $\mathrm{C}$ is an important antioxidant in extracellular fluid and inhibits the peroxidation of unsaturated lipids by scavenging or quenching free radical [7]. Vitamin C may prevent certain type of oxidative damage produced by infiltrating macrophages and neutrophils within the inflamed colon. The chemo preventive effects elicited by these natural dietary compounds are believed to include anti-oxidative, anti-inflammatory activity, induction of phase II enzymes, apoptosis, and cell cycle arrest [8].

\section{Types of Cancer}

\section{Carcinoma}

Carcinoma is a malignant neoplasm of epithelial origin. It is a tumor that arises in the tissues that line the body's organs like the nose, the colon, the penis, breasts, prostrate, urinary bladder, and the ureter. About $80 \%$ of cancer cases [9] are carcinomas [10]. The diagnosis of breast cancer falls into two broad categories, either estrogen receptor (ER)-positive or ER-negative, based on the level of ER in the cancer cells [11].

\section{Sarcoma}

Sarcomas are tumors that originate in bone, muscle, cartilage, fibrous tissue or fat. Ewing sarcoma (Family of tumors) and Kaposi`s sarcoma are the common types of sarcomas [12].

\section{Leukemia}

Leukemia's are cancers of the blood or blood-forming organs. When leukemia develops, the body produces a large number of abnormal blood cells. In most types of leukemia, the abnormal cells are white blood cells.

\section{Lymphoma}

Lymphomas affect the lymphatic system, a network of vessels and nodes that acts as the body`s filter. The lymphatic system distributes

*Corresponding authors: Subrahmanyam.V, Department of Biochemistry, University of Hyderabad, Hyderabad, E-mail: v.subrahmanyam99@gmail.com

Radhika.P.Ramachandran, Department of Biotechnology, Faculty of Engineering and Technology, SRM University, Chennai, India, E-mail: radhika.mtechbio@gmail.com

Received November 08, 2011; Accepted December 21, 2011; Published December 23, 2011

Citation: Subrahmanyam V, Radhika PR (2011) Significance of Dietary Antioxidants in Averting Cancer. J Carcinogene Mutagene 2:127. doi:10.4172/2157 2518.1000127

Copyright: (c) 2011 Subrahmanyam V, et al. This is an open-access article distributed under the terms of the Creative Commons Attribution License, which permits unrestricted use, distribution, and reproduction in any medium, provided the original author and source are credited. 
nutrients to blood and tissue, and prevents bacteria and other foreign "invaders" from entering the bloodstream.

\section{Adenomas}

Adenomas are cancers that arise in the thyroid, the pituitary gland, the adrenal gland, and other glandular tissues [13].

\section{What Causes Cancer?}

\section{Radiation}

High levels of radiation like those from radiation [14] therapies and $\mathrm{x}$-rays (repeated exposure) can damage normal cells and increase the risk of developing leukemia, as well as cancers of the breast, thyroid, lung, stomach and other organs $[15,16]$.

\section{Ultraviolet (UV) radiation}

UV radiations from the sun are directly linked to melanoma and other forms of skin cancer. These harmful rays of the sun cause premature aging and damage the skin. Artificial sources of UV radiation, such as sun lamps and tanning booths, also increase the risk of skin cancer. By wearing protective clothing and sunscreens and by avoiding prolonged exposure to the sun, one may reduce the risk of skin cancer [17]

\section{Viruses}

Some viruses, including hepatitis B and C, human papillomaviruses (HPV) [18], and the Epstein Barr virus, which causes infectious mononucleosis, have been associated with increased cancer risk. Immune system [19] diseases, such as AIDS, can make one more susceptible to some cancers.

\section{Toxins}

Bacterial protein toxins are among the most potent cell-killing molecules known [20].

\section{Chemicals}

Long term exposure to chemicals such as pesticides, uranium [21], nickel, asbestos, radon and benzene can increase the risk of cancer. Such carcinogens may act alone or in combination with another carcinogen, such as cigarette smoke, to increase the risk of cancer and other lung diseases [22].

\section{Tobacco}

Cigarette smoking and regular exposure to tobacco smoke greatly increase lung cancer [23]. Cigarette smokers are more likely to develop several other types of cancer like those of the mouth, larynx, esophagus, pancreas, bladder, kidney and cervix [24]. Smoking may also increase the likelihood of developing cancers of the stomach, liver, prostate, colon and rectum [25]. The uses of other tobacco products, such as chewing tobacco, are linked to cancers of the mouth, tongue and throat. The risk of cancer decreases soon after a smoker quits, while precancerous conditions often diminish after a person stops using smokeless tobacco.

\footnotetext{
Alcohol

Heavy drinkers face an increased risk of cancers of the mouth, throat, esophagus, larynx and liver. Some studies suggest that even moderate drinking may slightly increase the risk of breast cancer [26]. All cancers caused by cigarette smoking and heavy use of alcohol could be prevented completely.
}

\section{Diet}

High-fat, high cholesterol diets are proven risk factors for several types of cancer such as those of the colon, uterus and prostate. Obesity may be linked to breast cancer among older women as well as to cancers of the prostate, pancreas, uterus, colon and ovary. Many cancers that are related to dietary factors could be prevented. Healthy food choices and a well balanced diet including fiber, vitamins, minerals and low fat items may help to reduce cancer risk [27].

\section{Others}

Regular screening examinations by a health care professional can result in the detection of cancers of the breast, colon, rectum, cervix, prostate, testis, oral cavity, and skin at an earlier stage, when treatment is more likely to be successful. Self-examinations for cancers of the breast and skin may also result in detection of tumors at early stages. The screening-accessible cancers listed above account for about half of all new cancer cases. Primary ovarian carcinoid tumors are very rare; they represent less than $0.1 \%$ of all ovarian cancers [28].

\section{Hereditary risk factors}

Twenty percent of cancers are hereditary. This means that the abnormal gene responsible for causing cancer is passed from parent to child, posing a greater risk for that type of cancer in all descendants of the family. However, just because someone has a cancer-causing gene doesn 't mean they will automatically get cancer. If hereditary cancer is suspected, family members should consider genetic counseling and testing to determine their risk. If diagnosed in the early stages, such cancers are most responsive to treatment [29]. Multiple Or Bilateral Cancers In Families In some families, cancers of one or more types develop in several family members significantly more often than the average cancer occurrence. Families with above average occurrence of breast cancer, for example, have been observed to have more cancers of the ovary, colon, or endometrium (body of the uterus) than expected. Osteosarcoma (OS) is the most frequent primary malignant tumor of the skeletal system in children and young adolescents [30].

\section{Infection}

Some viruses are linked to certain cancers. For example, people with persistent infection with the hepatitis $B$ virus or the hepatitis $C$ virus [31] have an increased risk of developing cancer of the liver. Another example is the link between the human papillomavirus (HPV) and cervical cancer. Most (possibly all) women who develop cervical cancer have been infected with a strain (subtype) of HPV at some point in their life. But, most viruses and viral infections are not linked to cancer [32].

\section{Immune system}

People with a poor immune system have an increased risk of developing certain cancers. For example, people with AIDS [33], or people on immunosuppressive therapy.

\section{Rare or Unusual Types of Cancers}

Soft tissue sarcomas of the head and neck are rare mesenchymal malignant neoplasms [34].

\section{Antioxidants}

Antioxidants are the agents which are having the capacity of delaying or to stop the oxidation processes [35], which is occurring under the influence of atmospheric oxygen or reactive oxygen species 
[36]. By involving in the defense mechanism of the organism against the pathologies which are associated to the attack of free radicals, antioxidants can prevent the formation of free radicals. Anti oxidants works as enzymes, like superoxide dismutase, catalase, glutathione peroxidase or non enzymatic compounds, such as uric acid, bilirubin [37], albumin, metallothioneins. Endogenous Antioxidants can works as nutritional supplements [38] or pharmaceutical products, containing as active medicaments.

Epidemiological studies suggest that cancer incidence increased in last few years in Asian population [39]. Cancer is the second leading cause of death in the world after cardiovascular diseases [40]. So, there should be prevention method using the dietary supplements. Antioxidants are substances that may protect your cells against the effects of free radicals. Free radicals are molecules produced when your body breaks down food, or by environmental exposures like tobacco smoke and radiation. Free radicals can damage cells, and may play a role in heart disease, cancer and other diseases [41].

\section{Sources of Antioxidants}

Antioxidants are abundant in fruits and vegetables, as well as in other foods including nuts, grains, and some meats, poultry, and fish. The list below describes food sources of common antioxidants.

\section{Natural compounds}

Vitamin E, vitamin C (Ascorbic Acid) [42], $\beta$-carotene, vitamin E, flavonoids, minerals [43], vitamin D and vitamin K3 [44], Lutein, Lycopene, Selenium.

\section{Synthetic compounds}

Butylhydroxyanisole, Butylhydroxytoluene, Gallates, etc are also called as Neutraceuticals

In fact antioxidants are not only preventing the deleterious of free radicals [45] in the human body but also capable in the deterioration of fats [46] and other constituents of food stuffs [47].

\section{Ideal features of antioxidants:}

$>$ Capable to work at minute concentrations

$>$ Should not cause harmful effects

$>$ Should be in a pleasant flavor, odor

$>$ Should be easily soluble in fat

$>$ Easily available $\&$ inexpensive

\section{Benefits of Antioxidants}

Antioxidants play a major role in the prevention of formation of free radicals and oxidative stress, cancer prophylaxis and therapy. By having the active component of tyrosine [48] or other phenol oxidases these phenols and poly phenols target analytes can be detected in many cancers [49-60]. Antioxidants are plays an important role in the aging [61] factor so can there might be a less chance of oxidation in the human body [62].

The epidemiological studies suggests that fruits and vegetables are the best protection against the development of diseases caused by oxidative stress, such as cancer, type 2 diabetes [63] obesity, coronary heart disease, [64] hypertension and [65] cataract [66].
In addition to antioxidants fruits and vegetables also contains the dietary plants such as arytenoids, benzoic acid derivatives, phenolic compounds [67], flavonoids, ligans, ligins, proanthocyanides, stilbenes, coumarins [68] spices, berries, chocolate, cereals, nuts or seeds blackberries, walnuts, strawberries, artichokes, cranberries, brewed coffee, raspberries, pecans, blueberries, ground cloves, grape juice and unsweetened baking chocolate were also contains good amount of antioxidants [69].

Fruit juices, beverages and hot drinks contains good amounts of antioxidants, like polyphenols, vitamin C, vitamin E, [70]. Maillard reaction products, $\beta$-carotene, and lycopene [71]. Epidemiologic studies suggest that the usage of fruit juices, beverages and hot drinks was found to decrease the morbidity and mortality caused by degenerative diseases [72-77]. The total antioxidant potential is one of the key factors in investigating the relationship between dietary antioxidants [78] in cardiac [79] and distal gastric cancer [80] caused by the oxidative stress [81]. Usage of fruits and vegetables, as well as of grains and nuts involved in the decreasing the risk/occurrence of the chronic diseases [82-83]. Phytochemicals, plant derived molecules containing the antioxidant power can play against the chronic diseases [85].

Fiber rich foods contains good amount of phenolics are plays a major role in the prevention of chronic diseases such as neurologic disorders [86] these are also one of the sources of antioxidants [87]. By consuming high amount of flavonoids, human body can enhance the anti-proliferative and anti-inflammatory activity, [88] so can there might be a chance in the prevention of cancer and inflammatory diseases [89].

\section{Role of Dietary Antioxidants in Cancer}

The antioxidant activity of dietary nutrients is also susceptible to its environment, the presence of proteins and other antioxidants.

\section{Formation of Free Radicals}

Free radicals and other reactive oxygen species are derived either from normal essential metabolic processes in the human body or from external sources such as exposure to X-rays, ozone, cigarette smoking, air pollutants and industrial chemicals [90]. Some internally generated sources of free radicals are [91-93].

- mitochondria

- phagocytes

- xanthine oxidase

- reactions involving iron and other transition metals

- arachidonate pathways

- peroxisomes

- exercise

- inflammation

- Ischaemia /reperfusion.

Some externally generated sources of free radicals are

- cigarette smoke

- environmental pollutants

- radiation 
Citation: Subrahmanyam V, Radhika PR (2011) Significance of Dietary Antioxidants in Averting Cancer. J Carcinogene Mutagene 2:127. doi:10.4172/2157-2518.1000127

Page 4 of 7

- ultraviolet light

- certain drugs, pesticides, anaesthetics and industrial solvents

- ozone

Rancidity is also one of the factors which form the free radicals in cells. Rancidification is the decomposition of fats, oils and other lipids by hydrolysis or oxidation, or both. Hydrolysis will split fatty acid chains away from the glycerol backbone in glycerides. Antioxidants are often added to fat-containing foods in order to retard the development of rancidity due to oxidation [94].

\section{Initiation}

In the above reaction $\mathrm{LH}$ is the substrate molecule, for example, a lipid, with R. as the initiating oxidizing radical, [95] A highly reactive allyl radical (L.) is generated from the lipid in the above oxidation reaction, this allyl radical can able to react with the oxygen and forms a lipid peroxyl radical (LOO.).

\section{Propagation}

By means of oxidation with the lipid the peroxyl radicals further produces a lipid hydroperoxides ( $\mathrm{LOOH})$, these hydroperoxides break down to a broad range of compounds, like radicals, ketones, alcohols, alkyl formats, aldehydes, [96] and hydrocarbons, including the alkoxyl radical (LO·).

\section{Branching}

$\mathrm{LOOH} \rightarrow \mathrm{LO} \cdot+\mathrm{HO}$.

$2 \mathrm{LOOH} \rightarrow \mathrm{LOO} \cdot+\mathrm{LO} \cdot+\mathrm{H}_{2} \mathrm{O}$

These lipid hydroperoxides [97] often involved in transition metal ion catalysis, in reactions parallel to those involved in hydrogen peroxide, and yields lipid peroxyl [98] and lipid alkoxyl radicals.

\section{Termination}

Termination reactions have the combination of radicals to form non-radical products:

$$
\begin{aligned}
& \text { LO + LO } \\
& \text { LOO + LOO. } \\
& \text { LO + LOO. }
\end{aligned}
$$

These Primary antioxidants may either delay or inhibit the initiation step by reacting with a lipid radical or inhibit the propagation step by reacting with peroxyl or alkoxyl radicals [99].

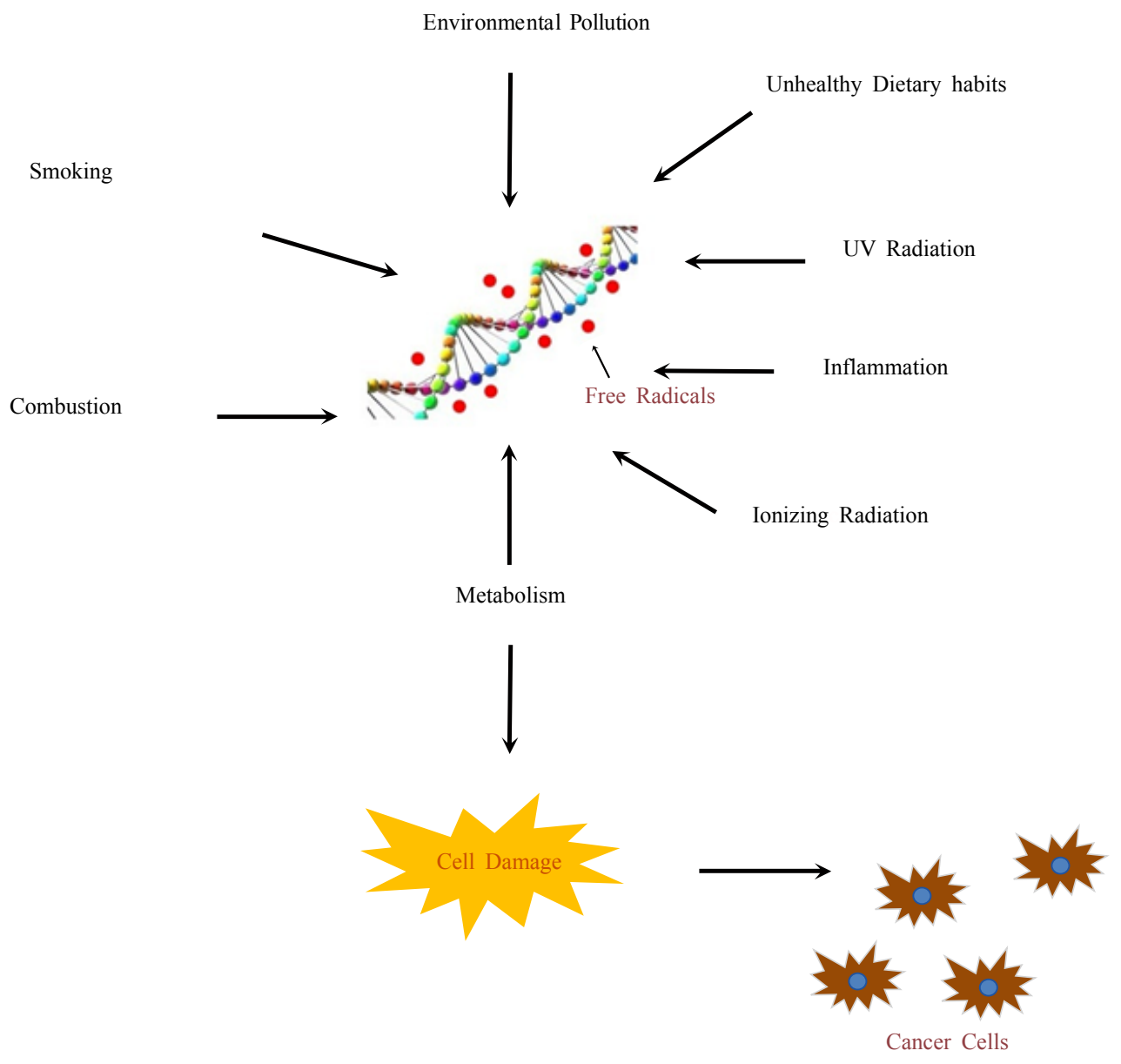

Figure 1: Formation of free Radicals. 


\section{Mechanism of Action of Antioxidants on Free Radicals}

The antioxidants decrease the adverse effect of reactive oxygen [100]. These Reactive Oxygen Species (ROS) include hydroxyl radicals $(\cdot \mathrm{OH})$, superoxide anions $\left(\mathrm{O}^{2}-\right)$, singlet oxygen $\left({ }^{1} \mathrm{O}_{2}\right)$, hydrogen peroxides $\left(\mathrm{H}_{2} \mathrm{O}_{2}\right)$, organic peroxides $(\mathrm{R}-\mathrm{OOH})$, and nitric oxide, peroxynitrite which are formed due to various environmental and dietary factors. Antioxidants heal these free radicals by providing them with the missing electron, so that they don't attack other cells and deprive them of electrons, so the damage to these cells is minimized. Additionally, antioxidants can restore a cell to its original condition, repairing the damage done to it by free radicals. Antioxidants also help to convert the free radicals into waste that is then ultimately removed from the body (Figure 1).

\section{Conclusion}

By this we can conclude that dietary antioxidants can provide a wide sort of health benefits, caused by the in the presence of free radicals on key biomolecules like lipids or nucleic acids. We can also prevent the various diseases which are occurring in the presence of Reactive Oxygen Species (ROS) like cancer and oxidative stress related diseases.

\section{References}

1. Kerr JFR, Winterford CM, Harmon BV (1994) Apoptosis. Its significance in cancer and cancer Therapy. Cancer 73: 2013-2026.

2. Mihaylov IB, Lerma FA, Moros EG (2010) Relation Between Tumor Size and Range of Motion in IMRT Treatment Planning for Thoracic Lesions. J Cancer Sci Ther 2: 100-104.

3. Pan MH, Ho CT (2008) Chemopreventive effects of natural dietary compounds on cancer development. Chem Soc Rev 37: 2558-2574.

4. Schmidt W, Popham RE (1981) The role of drinking and smoking in mortality from cancer and other causes in male alcoholics. Cancer 47: 1031-1041.

5. Steinberg D, Parthasarathy S, Carew TE, Khoo JC, Witztum JL (1989) Beyond cholesterol: modifications of low-density lipoprotein that increase its atherogenicity. N Engl J Med 320: 915-924

6. Enstrom JE, Kanim LE, Klein MA (1992) Vitamin C intake and mortality among a sample of the United States population. Epidemiology 3: 194-202.

7. Ascherio A, Stampfer MJ, Colditz GA, Rimm EB, Litin L, et al.(1992) Correlations of vitamin $A$ and $E$ intakes with the plasma concentrations of carotenoids and tocopherols among American men and women. J Nutr 122: 1792-1801.

8. Mukhopadhyay B, Mukhopadhyay K (2011) Applications of the Carrier Free Radioisotopes of Second Transition Series Elements in the Field of Nuclear Medicine. J Nucl Med Radiat Ther 2:115.

9. Skogseth H, Tvedt KE, Halgunset J (2011) Carcinoma Metastasis - An Approach to Models. J Carcinogene Mutagene 2:119.

10. Ferreira AK, Meneguelo R, Neto SC, Chierice GO, Maria DA (2011) Synthetic Phosphoethanolamine Induces Apoptosis Through Caspase-3 Pathway by Decreasing Expression of Bax/Bad Protein and Changes Cell Cycle in Melanoma. J Cancer Sci Ther 3: 053-059.

11. Bareggi Renato NV, Paola N (2010) New Targeted Therapies Against Breas Cancer. J Carcinogene Mutagene 1:110

12. Müller CR, Namløs HM, Bjerner J, Østensen IHG, Sæter G, et al. (2010) Characterization of Treatment Response to Recombinant Interferon- 2b in Osteosarcoma Xenografts. J Cancer Sci Ther 1: 016-025

13. Sangro B, Iñarrairaegui M (2011) Radioembolization for Hepatocellular Carcinoma: Evidence-Based Answers to Frequently Asked Questions. J Nucl Med Radiat Ther 2:110.

14. Riley JM, Jenrette JM, Gordon L, Milligan L, Zauls AJ, et al. (2011) Progression of Nodular Lymphocyte-Predominant Hodgkin's Lymphoma to a High- Grade Lymphoma. J Cell Sci Ther S2:001.
15. Onishi $\mathrm{H}$, Katano M (2011) Hedgehog signaling pathway as a therapeutic target in various types of cancer. Cancer Science 102: 1756-1760.

16. http://www.wisegeek.com/what-is-adenoma.htm

17. Coetzee K, Omoshoro-Jones J, Michelow P (2011) Carcinosarcoma of the Gallbladder Arising in a Patient with Pancreaticobiliary Maljunction: A Case Report and Review of the Literature. J Cytol Histol 2:115

18. Achhra AC, Zhou J, Dabis F, Pujari S, Thiebaut R, et al. (2010) Difference in Absolute CD4+ Count According to CD4 Percentage between Asian and Caucasian HIV-Infected Patients. J AIDS Clinic Res 1:101.

19. Song WZ, Wang Z, Li LW, Chen JH, Wang J (2010) Evaluation of Early Response to Neoadjuvant Chemotherapy in Breast Cancer Patients by 18F-FDG and 99mTc-HL91 Imaging. J Nucl Med Radiat Ther 1:102

20. Nigam A, Singh AK, Singh SK, Singh N, Singh N, et al. (2011) Primary Mammary (Non-Hodgkin) Lymphoma of Breast: A Case Report. J Cancer Sci Ther 3: 173-175

21. Sethy NK, Jha VN, Shukla AK, Sahoo SK, Tripathi RM, et al. (2011) Natura Radionuclide ( $U$ and ${ }^{226} \mathrm{Ra}$ ) in Water, Sediment, Fish and Plant Species in the Aquatic Environment around Uranium Mining and Ore processing Site at Jaduguda, India. J Ecosys Ecograph 1:103.

22. Debta P, Debta FM, Chaudhary M, Wadhwan V (2011) Evaluation of Prognostic Significance of Immunological Cells (Tissue Eosinophil and Mast Cell) Infiltration in Oral Squamous Cell Carcinoma. J Cancer Sci Ther 3: 201-204.

23. Marijani R, Abonyo BO (2011) CTP: Phosphocholine Cytidyltransferase Alpha (CCTa) siRNA Induce Cell Death of Lung Cancer Cells. Pharm Anal Acta 2:121.

24. Marimuthu A, Jacob HKC, Jakharia A, Subbannayya Y, Keerthikumar S, et al (2011) Gene Expression Profiling of Gastric Cancer. J Proteomics Bioinform 4: 074-082.

25. http://cancer.stanford.edu/skincancer/skin/causes/uvrad.html

26. McBee WC Jr, Gardiner AS, Edwards RP, Lesnock JL, Bhargava R, et al (2011) MicroRNA Analysis in Human Papillomavirus (HPV)-Associated Cervical Neoplasia and Cancer. J Carcinogene Mutagene 1:114.

27. Lechleider R, Pastan I (2011) Advances in the Development of Anti-CD22 Immunotoxins Containing Pseudomonas Exotoxin for Treatment of Hematologic Malignancies. J Cancer Sci Ther 3: 050-052.

28. Singh RK, Sudhakar A, Lokeshwar BL (2011) From Normal Cells to Malignancy: Distinct Role of Pro-inflammatory Factors and Cellular Redox Mechanisms. J Cancer Sci Ther 3: 070-075.

29. Kikuta K, Tsunehiro Y, Yoshida A, Tochigi N, Hirohahsi S, et al. (2009) Proteome Expression Database of Ewing sarcoma: a segment of the Genome Medicine Database of Japan Proteomics. J Proteomics Bioinform 2: 500-504.

30. Costa JV, Garbi Novaes MRC, Asquieri ER (2011) Chemical and Antioxidant Potential of Agaricus sylvaticus Mushroom Grown in Brazil. J Bioanal Biomed 3: 049-054.

31. Geetha BV, Navasakthi R, Padmini E (2010) Investigation of Antioxidant Capacity and Phytochemical Composition of Sun Chlorella -An Invitro Study. J Aquac Res Development 1:104.

32. Hsueh JT, Hwang KS, Pai L, Shih YL, Liaw JJ, et al. (2011) Effects of Lipofundin $\AA$ on the Measurement of Total Bilirubin by Spectrophotometry. $J$ Steroids Hormon Sci S4:001.

33. Roy D, Guha P, Bandyopadhyay D, Sardar P, Chatterjee SK (2011) Pancytopenia with Hemophagocytic Syndrome Associated with Histoplasmosis in Acquired Immunodeficiency Syndrome: Description of 2 Case Studies and Literature Review. J AIDS Clinic Res 2:115.

34. Johnson L, Fabre Nys C, Chanvallon A, François D, Fassier T, et al. (2011) Condition on the Pituitary and Ovarian Responses of Anoestrous Ewes to the "Ram Effect". J Veterinar Sci Technol S2:001.

35. Singh RK, Sudhakar A, Lokeshwar BL (2010) Role of Chemokines and Chemokine Receptors in Prostate Cancer Development and Progression. J Cancer Sci Ther 2: 94-99.

36. Sudhakar A (2009) Oral Submucous Fibrosis: Review on Etiopathogenesis. J Canc Sci Ther 1: 1-4. 
37. Knekt P, Reunanen A, Jarvinen R, Seppanen R, Heliovaara M (1994) Antioxidant vitamin intake and coronary mortality in a longitudinal population study. Am J Epidemiol 139: 1180-1189

38. Sawant L, Prabhakar B, Pandita N (2010) Quantitative HPLC Analysis of Ascorbic Acid and Gallic Acid in Phyllanthus Emblica. J Anal Bioanal Techniques 1:111.

39. Aberoumand A (2011) Protein, Fat, Calories, Minerals, Phytic acid and Phenolic In Some Plant Foods Based Diet. J Food Process Technol 2:114.

40. da Silva SB, Costa JP, Pintado ME, Ferreira DC, Sarmento B (2010) Antioxidants in the Prevention and Treatment of Diabetic Retinopathy - A Review. J Diabetes Metab 1:111.

41. Isakov N (2011) Differential Requirements for Protein Kinase C-Theta at The Immunological Synapse of Effector Versus Regulatory T Cells and Their Clinical Implications. J Clin Cell Immunol 2:e104.

42. Tint D, Anghel M, Lupu DS, Fischer LM, Niculescu MD (2011) Low dose Flaxseed Oil Supplementation Alters the Fatty Acids Profile and the Progression of Metabolic Syndrome in Men without Adequate Medical Treatment. J Nutrition Disorder Ther S7:001.

43. Molyneux $P$ (2004) The use of the stable free radical diphenylpicrylhydrazyl (DPPH) for estimating antioxidant activity. Songklanakarin J Sci Technol 26: 211-219.

44. Skogseth H, Tvedt KE, Halgunset J (2011) Inhibitors of Tyrosine Kinases (TKI) and Small Interfering RNAs (siRNA) are Promising Targeted Cancer Treatments. J Carcinogene Mutagene 2:122

45. Ly SY (2008) Voltammetric analysis of DL-a-tocopherol with a paste electrode. J Sci Food Agric 88: 1272-1276.

46. Kong YT, Imabayashi SI, Kano K, Ikeda T, Kakiuchi T (2001) Peroxidasebased amperometric sensor for the determination of total phenols using twostage peroxidase reactions. Am J Enol Vitic 52: 381-385.

47. Mena ML, Carralero V, Gonzalez-Cortes A, Yanez-Sedeno P, Pingarron JM (2007) Bioelectrochemical evaluation of the total phenols content in olive oil mill wastewaters using a tyrosinase-colloidal gold-graphite-Teflon biosensor. Int J Environ Anal Chem 87: 57-65.

48. Granero AM, Fernandez H, Agostini E, Zon MA (2008) An amperometric biosensor for trans-resveratrol determination in aqueous solutions by means of carbon paste electrodes modified with peroxidase basic isoenzymes from brassica napus. Electroanalysis 20: 858-864.

49. Zoulis NE, Efstathiou CE (1996) Preconcentration at a carbon-paste electrode and determination byadsorptive-stripping voltammetry of rutin and other flavonoids. Anal Chim Acta 320: 255-261.

50. Volikakis GJ, Efstathiou CE (2000) Stripping voltammetry using nujol-graphite and diphenylether-graphite paste electrodes. Talanta 51: 775-785.

51. Korbut O, Buckova M, Labuda J, Gruendler P (2003) Voltammetric detection of antioxidative properties of flavonoids using electrically heated DNA modified carbon paste electrode. Sensors 3: 1-18.

52. Cummings EA, Mailley P, Linquette-Mailley S, Eggins BR, McAdams ET, et al. (1998) Amperometric carbon paste biosensor based on plant tissue for the determination of total flavanol content in beers. Analyst 123: 1975-1980.

53. Eggins BR, Hickey C, Toft SA, Zhou DM (1997) Determination of flavonols in beers with tissue biosensors. Anal Chim Acta 347: 281-288.

54. Cummings EA, Linquette-Mailley SC, Mailley $P$, Cosnier S, Eggins BR, et al. (2001) A comparison of amperometric screen printed carbon electrodes and their application to the analysis of phenolic compounds in beers. Talanta 55: 1015-1027.

55. Busch JLHC, Hrncirik K, Bulukin E, Boucon C, Mascini M (2006) Biosensor measurements of polar phenolics for the assessment of the bitterness and pungency of virgin olive oil. J Agric Food Chem. 54: 4371-4377.

56. Labuda J, Buckova M, Heilerova L, Caniova-Ziakova A, Brandsteterova E, et al. (2002) Detection of Antioxidative Activity of Plant Extracts at the DNAModified Screen-Printed Electrode. Sensors 2: 1-10.

57. Kim HJ, Chang SC, Shim YB (2002) Cyclodextrin modified screen printed graphite electrodes for detection of phenols. Bull Korean Chem Soc 23: 427 431.

58. Capannesi C, Palchetti I, Mascini M, Parenti A (2000) Electrochemical sensor and biosensor for polyphenols detection in olive oils. Food Chem 71: 553-562.

59. Romani A, Minunni M, Mulinacci N, Pinelli P, Vincieri FF, et al. (2000) Comparison among differential pulse voltammetry, amperometric biosensor, and HPLC/DAD analysis for polyphenol determination. J Agric Food Chem 48 1197-1203.

60. Shirode AB, Sylvester PW (2011) Mechanisms Mediating the Synergistic Anticancer Effects of Combined $\mathrm{y}$-Tocotrienol and Celecoxib Treatment. J Bioanal Biomed 3: 001-007.

61. Turconi G (2011) Healthy Aging: Nutritional Intervention to Improve and Extend Quality of Life among Older People. J Nutr Food Sci 1:e101.

62. Aggarwal N, Shishu (2011) A Review of Recent Investigations on Medicinal Herbs Possessing Anti-Diabetic Properties. J Nutrition Disorder Ther 1:102.

63. Zubairi R (2011) Arrhythmia Susceptibility and Management in Adult Patients with Repaired Tetralogy of Fallot. J Clinic Experiment Cardiol S3:001.

64. Halvorsen BL, Holte K, Myhrstad MCW, Barikmo I, Hvattum E, et al. (2002) A systematic screening of total antioxidants in dietary plants. J Nutr 132: 461-471.

65. Chung CY, Yip PP, Tang HY, Yiu PF, Ho Leung NG, et al. (2011) A 10- year Review of Microbial pectrum of Post-cataract Surgery Endophthalmitis in Hong Kong Chinese. J Clinic Experiment Ophthalmol 2:160.

66. Dajanta K, Apichartsrangkoon A, Chukeatirote E (2011) Antioxidant properties nd total phenolics of thua nao (a Thai fermented soybean) as affected by Bacillus-fermentation. J Microbial Biochem Technol 3: 056-059.

67. Lindsay DG, Astley SB (2002) European research on the functional effects of dietary antioxidants-EUROFEDA. Mol Aspects Med 23: 1-38.

68. Halvorsen BL, Carlsen MH, Phillips KM, Bohn SK, Holte K, et al. (2006) Content of redox-active compounds (ie, antioxidants) in foods consumed in the United States. Am J Clin Nutr 84: 95-135.

69. Petrofsky JS, Mike Laymon D, Al-Nakhli HH, Cardinale L, Hermosura J, et al. (2011) The Effect of Vitamin D and E and Coenzyme Q-10 on Endothelia Function in a Young Population. Anatom Physiol 1:101.

70. Ramadan-Hassanien MF (2008) Total antioxidant potential of juices, beverages and hot drinks consumed in Egypt screened by DPPH in vitro assay. Grasas y aceites 59: 254-259.

71. Gillman MW, Cupples LA, Gagnon D, Posner BM, Ellison RC, et al. (1995) Protective effect of fruits and vegetables on development of stroke in men. J Am Med Assoc 273: 1113-1117.

72. Rimm EB, Aschiero A, Giovannucci E, Spiegelman D, Stampfer MJ, et al. (1996) Vegetable, fruits and cereal fiber intake and risk of coronary heart disease among men. J Am Med Assoc 275: 447-451.

73. Cohen JH, Kristal AR, Stanford JL (2000) Fruit and vegetable intakes and prostate cancer risk. J Natl Cancer Inst 92: 61-68.

74. La Vecchia C, Altieri A, Tavani A (2001) Vegetables, fruit, antioxidants and cancer: a review of Italian studies. Eur J Clin Nutr 40: 261-267.

75. Terry P, Terry JB, Wolk A (2001) Fruit and vegetable consumption in the prevention of cancer: an update. J Intern Med 250: 280-290.

76. Rodríguez-Bernaldo de Quirós A, Costa HS (2006) Analysis of carotenoids in vegetable and plasma samples: A review. J Food Compos Anal 19: 97-111.

77. Ramos-Jiménez A, Hernández-Torres RP, Wall-Medrano A (2011) Hatha Yoga Program Determinants on Cardiovascular Health in Physically Active Adult Women. J Yoga Phys Therapy 1:103.

78. Dodson MV, Hausman GJ (2011) Metabolic syndromes: Resolving a malady that involves numerous tissues, cells, regulators and regulatory pathways. $J$ Metabol Syndro 1:e101.

79. Turconi G, Simonetti P, Brusamolino A, Rondanelli M, Roggi C, et al. (2011) Nutritional and Plasma Antioxidant Status Assessment in a Group of Old Alzheimer's Inpatients. J Nutr Food Sci 1:101 
Citation: Subrahmanyam V, Radhika PR (2011) Significance of Dietary Antioxidants in Averting Cancer. J Carcinogene Mutagene 2:127. doi:10.4172/2157-2518.1000127

80. Serafini M, Bellocco R, Wolk A, Ekstrom AM (2002) Total antioxidant potential of fruit and vegetables and risk of gastric cancer. Gastroenterology 123: 985991

81. Pellegrini N, Serafini S, Del Rio SD, Bianchi M (2006) Total antioxidant capacity of spices, dried fruits, nuts, pulses, cereals and sweets consumed in Italy assessed by three different in vitro assays. Mol Nutr Food Res 50: 1030-1038.

82. Hu FB (2003) Plant-based foods and prevention of cardiovascular disease: an overview. Am J Clin Nutr 78: 544-551.

83. McCullough ML, Robertson AS, Chao A, Jacobs EJ, Stampfer MJ, et al. (2003) A prospective study of whole grains, fruits, vegetables and colon cancer risk. Cancer Cause Control 14: 959-970.

84. Rady MY, Verheijde JL, Potts M (2011) Quality Palliative Care or Physicianassisted Death: A Comment on the French Perspective of End-of-life Care in Neurological Disorders. J Clinic Res Bioeth 2:102e.

85. Pellegrini N, Serafini S, Del Rio SD, Bianchi M (2006) Total antioxidant capacity of spices, dried fruits, nuts, pulses, cereals and sweets consumed in Italy assessed by three different in vitro assays. Mol Nutr Food Res 50: 1030-1038.

86. Arazi HC (2011) Soluble Thrombomodulin Levels are Related to Inflammation after Coronary Bypass Surgery. J Clinic Experiment Cardiol 2:165.

87. Gazdik Z, Krska B, Adam V, Saloun J, Pokorna T, et al. (2008) Electrochemical determination of the antioxidant potential of some less common fruit species. Sensors 8: 7564-7570.

88. Haque SS (2011) Antioxidant Status of Formulated Drugs Against Typhoid Biochem \& Anal Biochem 1:101.

89. Celikyurt IK (2011) Thought-provoking Molecules for Drug Discovery: antioxidants. Pharm Anal Acta S3:001.

90. Kikuchi K, Miura N, Morimoto Y, Ito T, Tancharoen S, et al. (2011) Beneficial Effects of the Free Radical Scavenger Edaravone (Radicut) in Neurologic Diseases. J Neurol Neurophysiol S1.
91. Beaton GH (1994) Approaches to analysis of dietary data: relationship between planned analyses and choice of methodology. Am J Clin Nutr 59: 253-261.

92. http://www.cip.ukcentre.com/Rancidity.htm

93. Schmidt K (2011) Unrestricted vision. Biochem \& Anal Biochem 1:102e

94. Cheeseman KH, Slater TF (1993) An introduction to free radical biochemistry Br Med Bull 49: 481-493.

95. White HS, Smith L, Gentry T, Balber AE (2011) Mechanisms of Action of Human Aldehyde Dehydrogenase Bright Cells in Therapy of Cardiovascular Diseases: Expression Analysis of Angiogenic Factors and Aldehyde Dehydrogenase Isozymes. J Stem Cell Res Ther S1:001.

96. Verma OP, Ojha PK, Bailey SB, Singh P, Dubey R, et al. (2011) Isolation, Partial Purification and Characterization of Phospholipid Hydroperoxide Glutathione Peroxidase (Phgpx Enzyme from Oryza Sativa Seedlings. J Chem Eng Process Technol 2:120.

97. dos Santos RN, Silva MGV, de Freitas RM (2011) Crysophanol Effects on Lipid Peroxidation Levels and Catalase Activity in Mice Hippocampus after Pilocarpine-induced Seizures. J Cel Sci Therapy 1:104

98. Hassan W, Narayanaperumal S, Santos MM, Gul K, Mohammadzai IU, et al. (2011) Understanding the Mechanism of Antioxidant Potential of Organochalcogens in Rat's Brain Preparation. Pharm Anal Acta S3:002.

99. Spencer WA, Vadhanam MV, Jeyabalan J, Gupta RC (2011) Oxidative DNA damage following microsome/Cu(II)-mediated activation of the estrogens, $17 \beta$-estradiol, equilenin and equilin: Role of reactive oxygen species. Chem Res Toxicol.

100. Mascetti V, Gray K, Bennett M (2011) 13 Human plaque vascular smooth muscle cells show differential expression of genes associated with oxidative DNA damage. Heart 24: e8. 